https://doi.org/10.31470/2706-7904-2021-16-75-79

\title{
АССОЦИАТИВНАЯ КАРТИНА МИРА В ДИАХРОНИЧЕСКОМ АСПЕКТЕ
}

Associative Picture of the World in the Diachronic Aspect

\author{
Natalia Dmitryuk \\ Dr. Sc. in Philological, Professor \\ South Kazakhstan State Pedagogical University (Kazakhstan) \\ nvdmitr@yandex.ru. \\ https://orcid.org/0000-0002-8527-0338

\section{Rimma Arynbayeva} \\ Doctoral Student \\ South Kazakhstan State Pedagogical University (Kazakhstan) \\ rimma10.69@mail.ru \\ https://orcid.org/0000-0002-9181-539X
}

\begin{abstract}
The article is devoted to the study of the linguistic consciousness of Russians and Ukrainians in the diachronic aspect. The aim of the study is to determine the vector of displacement of the axiological component in the choice of estimates and preferences from among the basic values of informants-Slavs of different generations The material of the study was associative dictionaries compiled on the basis of associative experiments conducted in different periods. Currently, the world practice of associative research has accumulated a solid lexicographic material, recognized as one of the most reliable ways of access to the linguistic consciousness of man, which is understood by us as "ovneshnennye" linguistic signs of knowledge about the world, its projection in the mental apparatus of man-images of consciousness. This associative method of research of linguistic consciousness allows to explain the facts revealed in psycholinguistic experiments through their connection with ethno-cultural features and with their general cultural values.
\end{abstract}

Key words: associative dictionaries, stimulus, reaction, language consciousness.

\section{Вступление \\ Introduction}

Ассоциативные словари, созданные на основе свободных ассоциативных экспериментов (САЭ), представляют собой уникальный материал для исследования 
массового языкового сознания (ЯС), овнешненного ассоциативными реакциями, особенно формы его трансформации в период глобальных цивилизационных перемен.

Целью исследования является определение (а) стратегий ассоциирования представителей разных поколений восточных славян (русских и украинцев) на одни и те же вербальные стимулы и (б) векторов смещения (или устойчивости) оценок и/или предпочтений общечеловеческих или этноспецифических ценностей. Такое сопоставление способно оказаться перспективным и прогностическим как в плане межкультурных сравнений образов мира у сопоставляемых этносов, так и в плане внутриэтнического анализа ментальных и культуральных изменений этноса в период «цивилизационного слома», в частности, советской и постсоциалистической епохи.

\section{Методы исследования Methods of the Research}

Общей теоретической основой исследования послужила теория языкового сознания, разработанная Московской психолингвистической школой, в которой ассоциативные реакции рассматриваются как овнешненные словом образы сознания. Анализ вербальных связей внутри ассоциативных полей (АП) является действенным методом исследования массового языкового сознания. Обширный исследовательский материал в этой области представлен в многочисленных ассоциативных словарях разных языков. «С появлением ассоциативной лексикографии стало возможным смоделировать целостную картину мира «наивного» носителя языка / культуры... Материалы массовых ассоциативных экспериментов отражают реальное состояние обыденного сознания носителя определенного языка / культуры и могут использоваться как для анализа его синхронного состояния, так и для фиксации происходящих в нем изменений в диахронии при наличии нескольких временных срезов, указывающих на изменения в структуре ассоциативно-вербальной сети и в содержании знаний, стоящих за словом-стимулом, в зависимости от изменений, происходящих в социуме» (Уфимцева \& Балясникова, 2019: 7).

\section{Результаты}

\section{Results}

В рамках данной статьи мы выбрали для сравнительного анализа ассоциативные поля стимулов ЗЕМЛЯрус/ЗЕМЛЯукр. по материалам ассоциативных словарей А.А. Леонтьева (Леонтьев, 1977) и Н.П. Бутенко (Бутенко, 
1979) 1970-х годов и Славянского ассоциативного словаря (Уфимцева и др., 2004) пореформенного периода (САС-2004).

Обратимся к сопоставлению ассоциаций центральных зон АП в русском и украинском ассоциативных словарях советского и пореформенного периодов.

Данные по ассочиативным словарям А.А. Леонтьева и Н.П. Бутенко

Русск: Земля (725 всего): родная 66; круглая 63; черная 42; планета 40; небо 39; люди 25; и люди 19; сырая 16; вертится, теплая 15; моя 14; плодородная, шар 13; луна 11; наша 10; вода, людей, поле, русская, чернозем 9; почва 8; земной шар, матушка, Родина, рыхлая 7; кормилица, сухая, суша 6; жирная, мать, обетованная, отцуов, пухом, трава 5 (Леонтьев, 1977:102-103).

Укр: Земля (989 всего): чорна 196; кругла 88; родюча 62; рідна 39; багата 38; мати 30; тепла 25; грунт 24; велика, пухка 19; тверда 18; зорана, небо 17; чорнозем 15; планета 14; м'яка, наша, хліб 12; поле 9; волога 8; моя 7; батьків, болото, вода, годувальниця, куля, сира, холодна, щүедра 6; життя, космос, парувати, пахуча, прекрасна 5 (Бутенко, 1979:34-35).

\section{Данные по Славянскому ассоциативному словарю (САС)}

Русск: Земля (734 всего): круглая 79; планета 55; небо 50; вода 22; Родина 21; родная, шар 20; мать 16; почва, трава 14; вертится 13; черная 12; воздух, обетованная 11; в иллюминаторе 9; моя 8; плодородная 7; большая, кормилица 6; жизнь, Луна, хлеб, холодная 5 (Уфимцева и др.: 122).

Укр: Земля (633 всего): рідна 46; кругла 38; родюча 24; планета 23; чорна 21; життя 14; велика 13; грунт 11; хліб 10; небо 9; багатство, поле, робота 8; багата, годувальничя, чорнозем 7; город, наша, родючість 6; вода, люди, матінка, плодюча, щедра 5 (Уфимцева и др.: 123).

В словарях советского периода видим в центральной зоне АП стимула ЗЕМЛЯ совпадение пяти ассоциативных реакций из десяти самых частотных у русских и украинцев: родная 66, круглая 63, черная 42, теплая 15, плодородная 13 (27\%) // чорна 196, кругла 88, родюча 62, рідна 39, тепла 25 (41\%) - общее число совпадений 34\%, причем первые три самые частотные ассоциации заняли самые верхние ранговые позиции одинаково у русских и украинцев. Отметим среди типичных ассоциаций с положительной коннотацией соотношение реакций к стимулу «земля»: у русских родная, моя, теплая, наша, матуика, Родина, кормилица, мать, обетованная, отцов и др.; у украинцев - рідна, багата, мати, велика, матушка, Родина, батьків, м'яка, наша, прекрасна и др. Как видим, совпали 6 из 10 перечисленных ассоциаций активного ядра АП у русских и украинцев. Также актуальны для тех и других совпавшие нейтральные реакции планета, небо, поле, вода, шар/куля, чернозем/чорнозем и др, что составило $\mathbf{3 5 . 8 \%}$ совпадений в актуальной зоне АП стимула земля по данным 
словарей советского периода. По общему подсчету число совпадений в направлениях и содержании ассоциирования в центральной (первые 10 ассоциаций) и актуальной (с частотностью ответов 5 и более раз) зонах АП стимула земля составило 69.7\% у русских и украинцев (с учетом разного числа участников эксперимента).

Сопоставительный анализ совпадений в АП стимула земля по материалам Славянского ассоциативного словаря (Уфимцева и др., 2004) дает несколько иную картину: 4 совпадения из 10 зафиксированных наиболее частых реакций: круглая 79 / кругла 38, планета 55/23, небо 50/9 и родная 20/рідна 46 - соответственно $\mathbf{2 7 . 8 \%} / \mathbf{1 8 . 5} \%$ одинаковых ответов, что составляет $23 \%$ совпавших ассоциаций у русских и украинцев. Среди остальных актуальных (отмеченных 5 и более раз) положительных и нейтральных ассоциаций совпали 6 реакций: вода 22/5, черная 12 / чорна 21, плодородная 7 / родюча 24, родючість 6, плодюча 5, кормилщща 6 / годувальниця 7, жсизн 5 / життя 14, хлеб 5/хліб 10 - соответственно 57/92 ответа, или 7.7\% и 14.5\%. (11.3\%). Общее процентное число совпадений содержания ассоциаций русских и украинцев по материалам САС составило $\mathbf{3 4 . 3 \%}$, т.е. по сравнению с советским периодом общность направлений и содержания ассоциирования уменьшилась практически вполовину. Еще большая разница, как показывает опыт и аналитическая практика, проявится при подсчете единичных и малочастотных ассоциаций.

\section{Выводы \\ Conclusions}

Предпринятый нами анализ фрагмента языкового сознания (отраженного в ассоциациях образа мира) двух поколений русских и украинских респондентов обнаружил определенный градус смещения ценностных базовых ориентиров, которыми принято считать наиболее актуализированные, высокочастотные ассоциации в составе АП. При сопоставлении центральной и актуальной (с частотой 5 и более реакций) зон АП стимула земля единообразие, кажущееся на первый взгляд, в ответах двух поколений русских и украинских информантов (1970-х и 2004 гг.) при детальном статистическом анализе оказалось не столь убедительным: общий показатель совпавших ассоциаций в пореформенный период (34.3\%) оказался практически вдвое меньше, чем показатель их общности в советский период (69.7\%). Очевидное сходство образов сознания русских и украинцев середины прошлого века было обеспечено и закреплено в языках и культурах двух родственных восточнославянских народов, что при внешне благополучном соседстве новых образовавшихся суверенных государств, как оказалось, стало уже не столь 
единодушным, хотя в тот пореформенный период трудно было представить, как глубоко залегла трещина, разделяющая нас сегодня.

Ограниченный объем публикации не позволяет более широко представить результаты выполненного нами сопоставительного анализа (на примере АП стимулов человек, хлеб, семья и др., представляющих безусловные базовые ценности), но они объективно свидетельствуют о перспективности и прогностическом потенциале ассоциативной лексикографии (Дмитрюк, 2020: 152), что следует учитывать при построении модели межэтнического согласия и толерантности в условиях современных глобализирующихся государств.

\section{Литература References}

Бутенко, Н.П. (1979). Словник асоціативних норм украінськоі мови. Львів.

Дмитрюк, Н.В. (2020). Ассоциативные словари в Казахстане и казахстанские психолингвистические исследования. Вопросы психолингвистики, 1(43), 140-162 . http://dx.doi.org/10.30982/2077-5911-2020-43-1-140-161

Леонтьев, А.А. (1977). Словарь ассоичативных норм русского языка. М.: МГУ. www.prlib.ru Уфимцева, Н.В., \& Балясникова, О.В. (2019) Языковая картина мира и ассоциативная лексикография. Вестник Волгоградского гос. университета. Серия 2. Языкознание, 1 (18), 6-22. https://doi.org/10.15688/jvolsu2.2019.1.1

Уфимцева, Н.В., Черкасова, Г.А., Караулов, Ю.Н., \& Тарасов, Е.Ф. (2004). Славянский ассочииативный словарь: русский, белорусский, болгарский, украинский. Москва. https://t-claim.ru/Projects/ASIS/SAS 